\title{
O fantasma da literatura feminina
}

\section{The ghost of women literature}

\author{
Carola Saavedra*
}

A jovem escritora senta-se sorridente diante do entrevistador. Pronta para falar de seu novo livro, da polifonia, do enredo, da desconstrução da trama, das influências de Kant, Nietzsche, Kierkegaard. É quando ouve a fatídica pergunta: "Você, como representante da nova geração, o que acha da literatura feminina? Ela existe?”. A jovem escritora ajeita seus óculos de grau, faz cara de poucos amigos e afirma com veemência que tudo não passa de mito, lenda, intriga da oposição. Explica que as mulheres escrevem da mesma forma que os homens, que são os mesmos temas, as mesmas preocupaçôes. Prova por A mais B que o fato de ser mulher em nada influencia o livro que escreveu. O entrevistador sorri educadamente, mas não se mostra muito convencido.

Mas que significados estão embutidos nessa expressão, "literatura feminina"? Por algum tempo (especialmente nas décadas de 1960 e 1970), tratou-se de uma expressão que definiria e defenderia na literatura os direitos das mulheres num mercado que durante séculos as

* Escritora, autora de Flores azuis, Paisagem com dromedário, entre outros livros.

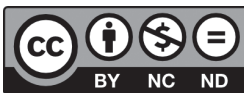

Esta obra está licenciada sob uma Licença Creative Commons. 
manteve num papel de musa, jamais de criadora. Hoje em dia, é coisa de mulherzinha, literatura de dona de casa, escrevinhaçóes de donzela chorosa. Na melhor das hipóteses, um epígono de Clarice Lispector; na pior, aparentada com os indefectíveis romances Julia e Sabrina que nos espreitam entre as revistas nas bancas de jornal. Enfim, com o passar dos anos, o termo literatura feminina tornou-se uma espécie de bichopapão. E, gostemos ou não, a verdade é que se a pergunta continua sendo feita, não é por implicância do entrevistador, mas porque há algo ali que ainda não foi resolvido, não encontrou sua resposta. É necessário então observar com cuidado de que fantasma se trata.

Olhando com atenção para o nosso fantasma, percebemos que ele nos faz algumas perguntas: Há algo no texto que diferencia um homem de uma mulher? Um lugar a partir do qual se escreve? Se a experiência do corpo é indiscutivelmente outra, não terá isso necessariamente um reflexo na construção da própria escrita? Se a ciência insiste em dizer que meninos e meninas reagem de forma diferente às diversas situaçóes, será que existem assuntos preferidos por mulheres e assuntos preferidos por homens? $\mathrm{Ou}$ será tudo uma questão de gênero, papéis ocupados independentemente do sexo? O fantasma nos devolve o olhar e solta uma gargalhada.

$\mathrm{Na}$ busca por respostas, iniciemos com uma breve retrospectiva. Comecemos pensando em quem eram as mulheres que escreviam. Até o final do século 19, elas praticamente não existiam, seja porque a maior parte pertencia a uma classe social que não permitia sequer o acesso à escolaridade, seja porque, quando se tinha acesso, no caso de famílias mais abastadas, na maioria das vezes não se admitia que gastassem seu tempo com veleidades artísticas ou intelectuais. Em outras palavras, lugar de mulher era em casa, junto ao marido, aos filhos, à mobília. Claro que havia exceções, as irmãs Brontë, Jane Austen, George Eliot, etc., o que de fato só faz confirmar a regra. No início do século 20, a situação começa a mudar, a mulher passa a ter maior acesso à escolaridade. Seu universo, porém, ainda é o da vida privada, da família. E isso, claro, se refletia em seus livros, afinal, dificilmente ela escreveria sobre intrigas internacionais, guerras, política, se o que conhecia, o seu mundo, estava restrito ao âmbito da casa. 
Chegam os anos 1960, 1970, e com eles novas mudanças, talvez as mais radicais: as mulheres saem da casa e passam a ocupar lugares antes exclusivos aos homens, surgem advogadas, executivas, engenheiras. É também a época em que adquire maior força a luta pelos direitos da mulher. Como é muito comum em momentos de embate, há uma radicalização dos papéis, e é também nessa busca por novos espaços que surgem conceitos totalizadores, entre eles o de literatura feminina.

A partir da década de 1990, a situação de certa forma se estabiliza, mulheres também trabalham fora, se preocupam com suas carreiras, homens também ficam em casa, se preocupam com a criação dos filhos, com a família - ou seja, homens e mulheres transitam igualmente entre o público e o privado. E essa nova constelação reflete-se, é claro, na literatura: dramas familiares e viagens pelo mundo, por exemplo, são narrados tanto por homens quanto por mulheres. Tentar decifrar o sexo do autor a partir de sua escrita torna-se um exercício de adivinhação. Em outras palavras, o texto perde as marcas de gênero, para apresentar apenas as diferenças individuais.

Voltamos entâo à questáo inicial. Se homens e mulheres ocupam papéis semelhantes e publicam livros não mais classificáveis quanto ao gênero, por que a pergunta ainda insiste? Por que o fantasma continua ali, olhando para nós com seu sorriso irônico? Talvez porque se trate de uma questão que ultrapassa a literatura, afinal, por mais mudanças que ocorram na sociedade, por mais que os papéis se aproximem e se misturem, continuamos nos fazendo as mesmas perguntas básicas, entre elas, o que é ser um homem, o que é ser uma mulher? À primeira vista a resposta pode parecer fácil, mas não é. Cientistas, sociólogos e psicanalistas continuam pensando e discutindo sobre ela. No que diz respeito exclusivamente à literatura, resta-nos aceitar que oferecer respostas não faz parte de sua essência - ao contrário. Mas talvez ela sugira novas perguntas que, por sua vez, possam nos ajudar a compreender melhor nosso lugar no mundo. De qualquer forma, à literatura interessa apenas o texto, seu valor literário, e como toda criação artística, se faz e se esgota independentemente de qualquer teoria. 
Quanto à nossa jovem autora, talvez daqui a 50 anos, ela, já não mais tão jovem, mas com vários livros publicados, diante do entrevistador, possa responder (sem que isso lhe provoque angústia): "Se existe uma literatura feminina? Talvez sim, talvez não. De qualquer forma, para a literatura, isso não tem a menor importância".

[Texto recebido em fevereiro de 2013, sendo publicado primeiramente em Rascunho, outubro de 2012]

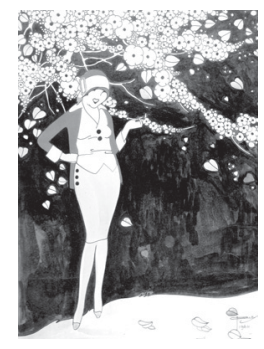

